\title{
12. Contesting the frame: opposition leadership and the global financial crisis
}

\author{
Brendan McCaffrie
}

\section{Whose crisis?}

The global financial crisis has dominated inter-party political contests in almost all major democracies, presenting challenges and opportunities to executive government leaders and opposition party leaders alike. In their public responses to crises, opposition leaders complete many comparable framing tasks to those of executive leaders. Opposition leaders, however, typically have lesser resources, fewer political weapons and limited responsibility for the real crisis response. These differences create a distinct and difficult challenge for opposition leaders in crises. Despite these restricted opportunities, opposition leaders can exploit crises for political gain. This chapter demonstrates how opposition leaders in three different political systems utilised the public sphere to do this, and explains their consequent political successes and failures.

Political opposition is understudied in political science, while opposition leadership is almost entirely neglected. This is unfortunate, as oppositions and opposition leaders are crucial to maintaining the accountability and legitimacy of governments, and as such should be better understood than they are. Opposition leadership can be defined in many ways. Traditionally, the term 'Leader of the Opposition' has been used in Westminster systems to refer to the leader of the largest non-government party in parliament. Moving beyond Westminster systems, this conception becomes problematic.

In presidential systems such as the United States, it is very often unclear who is leading the non-government party. In situations of divided government, when the president's party does not hold a majority in both houses of Congress, it can also be unclear which is the non-governing party. As Dahl (1966:34) notes of the United States, '[t]o say where the government "leaves off" and "the opposition" begins is an exercise in metaphysics'. Additionally, the definitional restriction to the largest non-government party cannot accurately represent different oppositional configurations displayed in multiparty coalition systems. For instance, after the 2005 German federal elections, the centre-right Christian Democrats (CDU/CSU) became the senior governing partner in a 'grand coalition' government with the centre-left Social Democratic Party (SPD). The CDU/CSU's preferred coalition partner, the Free Democratic Party (FDP), was the largest non-government party although it held only 61 of 614 Bundestag seats and was 
ideologically similar to the CDU/CSU. Moreover, it was clear from the post-election posturing of the SPD that the most significant opposition to the leadership of Chancellor, Angela Merkel, would come from within her own grand coalition government (Richter 2006).

This chapter does not investigate the roles of minor-party oppositional leadership or extra-parliamentary oppositional leadership in the financial crisis. The simplest term to describe the types of opposition leadership investigated here is 'alternative executive leadership'. Each of the opposition leaders discussed has been engaged in a legitimate attempt to replace the incumbent head of government. With this as the common goal, and bearing in mind the nature of the global financial crisis, it is unsurprising that opposition leaders focused on the third and fourth framing contests described in Chapter 2. Apportioning blame (third contest) and providing alternative policies (fourth contest) are opposition leaders' two strongest weapons.

They might find the first framing contest, which centres on defining the significance and severity of events, a more fruitful avenue of attack in other types of crisis than it was at the onset of this financial crisis. This is because oppositions typically rely on the same economic data as governments and have fewer economic experts at their disposal to interpret those data, making it difficult to contest government statements about the severity of negative economic events. Furthermore, offering a bleaker picture of the state of the economy than government leaders do leaves opposition leaders susceptible to claims that they are acting irresponsibly by diminishing consumer confidence and thereby damaging the economy. This difficulty was exemplified by Britain's Shadow Chancellor of the Exchequer, George Osborne, who warned of the potential for a run on the pound, only to be pilloried by the government, media and even his own party (Helm et al. 2008). This was a rare example of an opposition attempting to make a mark in the first framing contest. Given the outcome, this rarity is hardly surprising. In the cases studied, the first framing contest is a relatively minor one and therefore it is excluded from the analysis.

The second framing contest - in which political actors attempt to define the cause of a crisis - is crucial to opposition leaders' abilities to blame the government for the disaster. If a government leader effectively defines the crisis as caused by external events, it becomes virtually untenable for an opposition leader to claim that the government or its leader is culpable for the negative effects of the crisis. In the specific case of the financial crisis, it made little sense to define an opposition leader's causal frame as distinct from their blaming frame. Alternative government leaders gain nothing by offering a causal frame that does not, either directly or indirectly, apportion blame to the government. As such, these two framing avenues - causality and blame - will be examined together in section three of this chapter. 


\section{Cases and context: opportunities and expectations}

The three nations selected for analysis - the United Kingdom, the United States and Germany-are each considered archetypes for different systems of government. The United Kingdom has the original Westminster system and its opposition behaves almost exclusively as an alternative government. Since World War II, there has not been a coalition government and its only major deviation from a classic binary government-opposition dichotomy is a fairly strong third party, though typically it is not strong enough to prevent a majority government. The United States has a presidential system with a pure separation of powers. As such, it presents significant challenges in locating an opposition, let alone its leader. This chapter examines the period of the 2008 US presidential election campaign, as elections are perhaps the only time when both major parties have an obvious leader. They are certainly the only times when alternative government leaders can be readily identified. Germany is seen to epitomise consensus systems, with a proportional representation voting system and a growing history of coalition governments. The rise of the minor parties at the expense of the two major parties in recent times led to only the second German 'grand coalition' government, in 2005, although at the time of writing Germany was approaching an election with another grand coalition one likely possibility. This chapter defines the German alternative executive leader as the leader of the junior coalition party, which during the onset of the financial crisis was the SPD. Ordinarily, this would present a difficulty in that much of its opposition to the Merkel-led 'union' of CDU and CSU parties is not conducted in the public realm. Fortunately, the proximity of the September 2009 election and the SPD's decision to choose its chancellor candidate an entire year before the poll escalated the public nature of the SPD's opposition to the union parties.

\section{United Kingdom: a besieged government and a vulnerable economy}

The United Kingdom entered the financial crisis with a more immediately vulnerable economy than either Germany or the United States. Under the Labour Government, Britain had enjoyed a decade of immense prosperity, with the International Monetary Fund (IMF) declaring that between 1996 and 2005 the United Kingdom's 'growth of real GDP per capita was higher and less volatile than any other G7 country' (IMF quoted in Lee 2008:17). The consistently high exchange rate of the pound against other currencies in that period, however, discouraged exports and resulted in a poor balance of trade. Even with booming financial and business services sectors, which delivered almost 30 per cent of gross domestic product (GDP) (The Guardian 2007), the United Kingdom ran consistent trade and current account deficits (Lee 2008). This reliance on financial and business services coupled with a dependence on overseas borrowing meant 
that the financial crisis, with its sharp decline in lending, damaged Britain's economy severely and rapidly.

The Labour Government entered the financial crisis after more than a decade in office, but with the experienced Prime Minister, Tony Blair, having stepped aside for his long-time Chancellor of the Exchequer, Gordon Brown, in June 2007. Brown performed well in the polls during his first few months as leader, with Labour consistently leading its rival Conservative Party by single-figure margins (UK Polling Report 2009). Despite this leadership transition, Brown's long tenure as Chancellor meant that he was inextricably linked with the economic performance of the nation, especially as he had long boasted that his stewardship of the economy had resulted in 'the longest period of sustained economic growth since records began' (Brown quoted in Milne 2007).

Traditionally, the governing Labour Party was a centre-left social democratic party. The 'New Labour's' third-way politics broadly accepted a move towards a neo-liberal economic strategy (Heffernan 1999), although some commentators contested the extent to which this was the case (cf. Beech 2008). This meant that little distinguished the Conservative Party from the Labour Government on economic matters except for Labour's slightly greater predilection for public spending.

For Conservative Opposition Leader, David Cameron, who took on the role in December 2005, the economic situation and the length of the Labour Government's tenure combined to create strong opportunities to attack Brown and his government using blaming tactics. Brown essentially had responsibility for the economic system and had claimed responsibility for its successes. The severe hardship that Britain was to face in comparison with many other Western European nations would mean that as long as the public accepted Brown and his government as responsible for the crisis, or even just for its severity, Labour's popularity would slip. In the policy contest, however, the Conservatives would likely be hampered by their ideological proximity to the failing economic policies of the Labour Government. Cameron would be unable to press for a paradigm shift in economic policy and would be forced to focus on technical issues and specific policy failings of the Brown Government. Thus, the global financial crisis would provide significant but by no means unlimited opportunities for Cameron as opposition leader.

\section{United States: competing opposition leaders}

When the sub-prime mortgage crisis visibly struck the financial sector in March 2008 with the collapse of Bear Sterns investment bank, President, George W. Bush, was suffering unremittingly low approval ratings. A Gallup Poll published on 20 February 2008 (Saad 2008) found that 31 per cent of respondents approved of Bush's performance - a result that was strikingly similar to those of the 
preceding months. The Bear Sterns failure also coincided with the 2008 presidential election campaign. Polling suggested that presumptive Republican nominee, Senator John McCain, was roughly level with eventual Democratic nominee, Senator Barack Obama, with some polls favouring the Democrat and others the Republican (Real Clear Politics 2008). These polls should be treated with caution, as McCain had won the Republican nomination, while Obama was still battling Senator Hillary Clinton for the Democratic nomination, but they do show that each leader was in a reasonable position to utilise the crisis to their political advantage.

The financial crisis struck the United States at the end of the two-term Bush Republican presidency. In terms of apportioning blame, the unpopularity and apparent culpability of Bush made him an obvious target. With two presidential contenders who had not been part of the Bush Administration and had explicitly opposed it on many issues in the past, each could use blame tactics against Bush. This would be easier for Obama than McCain, as Obama could repudiate the entire Republican Party. It is also important to note that blaming the incumbent, though likely damaging to Bush, would be far less relevant than blaming the opposing candidate. This meant that the relevant argument could either shift to blaming the partisan ideology behind the crisis or to focus on the policy contest. Either argument would again likely favour Obama. The vehemently free-market Republicans were intractably associated with the ideology that public debate increasingly blamed for the crisis. They were also unlikely or even unable to argue for a policy shift, whereas the more centre-left Democrats could plausibly argue for stricter regulations of the finance sector. Therefore Obama had greater opportunities to use the weapons of blame and policy to exploit the crisis to his political advantage than did McCain.

\section{Germany: spot the opposition}

Compared with the other nations examined in this chapter, Germany felt the early effects of the financial crisis fairly moderately. Admittedly, the government was forced to bail out IKB Deutsche Industriebank AG on several occasions from mid 2007, and to rescue Hypo Real Estate in September 2008, after the Lehman Brothers collapse in the United States because of each of these lenders' exposure to the sub-prime crisis. Financial problems in Germany, however, remained largely distinct from the rest of the economy, which led Europe in managing 1.5 per cent growth in the first quarter of 2008 (Dougherty 2008). This was due largely to its strong and varied export sector. When the crisis made other nations less able to buy its goods, the German economy did falter (The Economist 2009). An idiosyncratic factor of the political and economic context in Germany is a deep fiscal conservatism that leads politicians to shun state intervention through stimulus packages and other similar measures (Bovensiepen et al. 2008). 
The German political context at the time of the crisis was intriguing. The 'grand coalition' government of SPD and union parties was an uneasy alliance between parties that had been staunch competitors since the State's founding in 1949-bar one period of an equally uneasy coalition imposed by political circumstances from 1966 to 1969. Condemned to collaboration by the election outcomes, the parties forged the coalition in a difficult negotiation process subsequent to the 2005 election. The masterful posturing skills of outgoing Chancellor, Gerhard Schröder, secured for the SPD a majority of cabinet positions, among them the highly important Finance Ministry, which was taken by Peer Steinbrück (Richter 2006). The negotiation phase also saw the Christian Social Union (CSU), the Bavarian sister party to the Merkel-led Christian Democratic Union (CDU), awarded the Economics Ministry, and from the time of the election until February 2009, the Economics Minister was the reluctant and economically uninterested Michael Glos. As a result of Glos's lack of economic acumen and Merkel's lack of trust in him, Steinbrück had far more involvement in economic decisions throughout the crisis (Nelles and Neukirch 2008). Glos's frustration at his own lack of influence led him to call publicly for the government to change policy and introduce tax cuts (Bovensiepen et al. 2008), and ultimately to resign in an unorthodox manner designed to embarrass Chancellor Merkel (cf. Crossland 2009). The significant input of Steinbrück had allowed the SPD a far greater opportunity to affect government policy in response to the crisis, but consequently limited its ability to blame the government for failing to prevent the crisis, or respond appropriately.

The SPD's legacy as the previous governing party further limited its potential to advocate a policy shift. Under Schröder, the SPD Government implemented a largely neo-liberal set of economic proposals known as 'Agenda 2010', which cut taxes, reduced welfare programs and reformed the labour market. Schröder's SPD was very strongly associated with the neo-liberal ideology and had been the senior governing party in a coalition government with the Green Party until 2005. Seemingly, it was in a poor position to cast blame on a centre-right party that had been in government for a comparatively short period. When Frank-Walter Steinmeier became the SPD chancellor candidate, this connection to the Agenda 2010 reforms intensified. Steinmeier had participated in the design of the program in the bureaucratic post of head of the Office of the Chancellor, where he was one of Schröder's political confidantes.

A further limitation on the SPD was its waning popularity. After performing better than expected in the 2005 election-garnering 34.3 per cent of the vote and forcing the grand coalition situation - the SPD's polling numbers declined. In the last few months of 2007, major polling agencies consistently recorded its support at between 25 and 30 per cent compared with the CDU/CSU's polling in the very high 30s (Der Spiegel 2009). Worse was to come after then party leader, Kurt Beck, reneged on a promise not to deal with the far-left Left Party 
and backed the bid by State of Hessen's SPD leader, Andrea Ypsilanti, to form a government there with the support of the Left Party. The Left Party's strong connections with the former East German regime made this a politically fraught situation. It caused ructions within the SPD on a national level and ultimately failed when rebel SPD member Dagmar Metzger in Hessen refused to accept her own party as a government (Deutsche Welle 2008a). Beck's popularity plummeted. A poll in March suggested that he was the preferred chancellor for only 13 per cent of voters, while also showing just 23 per cent support for the SPD Party (Der Spiegel 2008a). Beck was replaced as party leader in September 2008 by Franz Müntefering, while Foreign Minister and Deputy Chancellor, Frank-Walter Steinmeier, was announced as the SPD's chancellor candidate for the 2009 election, thus becoming the alternative government leader. The weak position of the SPD would appear to limit its ability to attack the CDU/CSU even further, particularly in the last months of Beck's party leadership, when speculation about his future was frequent.

Of the cases discussed here, the German opposition leadership was in the worst position to use the weapons of blame and policy change. It was handicapped by its high level of responsibility for the economic situation in having a two-term neo-liberal economic policy legacy to defend and in providing the most important minister in German economic matters to the current coalition government. Although traditionally the SPD had been the party of centre-left social democracy in Germany, it was in no position to advocate a major ideological shift in economic policy because of its close ties to the neo-liberal system in place. Furthermore, the political landscape was dominated by fiscal conservatism - with Merkel and Steinbrück each motivated by the long-term goal of a balanced budget rather than short-term attempts to ward off recession (Deutsche Welle 2008c).

\section{The second and third framing contests: causality and blame}

\section{United Kingdom: winning a blame showdown}

Opposition leaders rarely if ever treat causality as distinct from blame. This was exemplified by David Cameron's contention immediately after the run on Northern Rock bank in September 2007: that this was caused by too much public and private debt - a problem fostered by the Brown Government (Elliot and Seager 2007; Harding 2007). Cameron repeated this claim like a mantra throughout the financial crisis, clearly seeing an opportunity not only to blame the government for its part in creating the crisis but to undo the public perception that the Labour Government had managed the economy successfully in the past decade. He therefore claimed that the previous boom had been 'built on a mountain of debt' (Cameron quoted in Webster and Elliot 2007). 
In the immediate aftermath of the Northern Rock failure, Cameron struggled to make a political impact. In the first week or two after the news broke, Labour advanced from its slim advantage to a double-figure lead in several polls. This government bounce was short-lived, however, and by the second week in October most polling agencies showed the Conservatives in front (UK Polling Report 2009). The Northern Rock issue lingered for months. It was mid-February 2008 by the time the government decided to nationalise the institution, leading Cameron to argue that Chancellor of the Exchequer, Alistair Darling, should resign and that the Brown Government had failed by dithering over the nationalisation (Watt 2008a).

In continuing to promote the message that the Labour Government had done little to restrain debt, Shadow Chancellor of the Exchequer, George Osborne, noted in March 2008 that Brown had failed to prepare the country for possible tough times. Here, Osborne was careful not to suggest that a downturn had begun, merely claiming that there should always be emergency funds in case of one (Riddell 2008a). This allowed the Tories to avoid the appearance of a reckless party that endangered the economy by reducing public confidence. It also allowed them to avoid the risk of appearing economically ignorant by suggesting a major economic slump was on its way when it might not happen. In April, Osborne continued the pressure over the public debt, claiming that the United Kingdom had the largest budget deficit in the developed world. This statement, though perhaps not entirely accurate given the size of the US deficit (Milne 2008b), was an effective one, because it distinguished the UK situation from that of the rest of the developed world. It damaged counterclaims by Brown that the real cause of the financial crisis was the United States. Osborne and Cameron repeated this claim several times over many months, although eventually Osborne altered the phrasing from 'largest deficit' in the developed world to 'worst public finances' in the developed world (Webster et al. 2009).

The excessive-debt narrative served Cameron and Osborne well for the best part of six months, as the Conservatives continued a steady climb in the polls. From 4 May 2008 to 14 September 2008, in 40 voting-intention polls taken by major polling agencies, the Conservatives led by an average of 19 percentage points. The next week, the crisis reached its climax. The failure of Lehman Brothers in the United States and the ensuing market turmoil sparked a Labour poll revival (UK Polling Report 2009). At this point, the crisis changed in nature, and to help explain the collapse of financial institutions, a secondary causal and blaming tool became prominent. The Conservative leadership used the idea of a failure of financial regulation to blame the government for the financial crisis. Cameron and Osborne continued to make debt the principal issue, most likely because the Tories had little intention of making substantial alterations to the system of financial regulations themselves. Nevertheless, Osborne did take the opportunity 
to attack Brown for a failure of regulation (Webster and Elliot 2008; Wintour 2008).

On 30 September 2008, Cameron announced an unlikely policy of bipartisanship (Elliot and Wintour 2008). This was apparently in response to the failure of the United States to pass a bank bailout bill through Congress because of ideological party divisions. British bipartisanship was short-lived, lasting a little more than two weeks before the opposition leader began criticising Brown's crisis response, reverting to the debt narrative and labelling Brown's solution to the crisis 'borrowing and borrowing and borrowing' (Cameron quoted in Stratton 2008). Neither the bipartisan strategy nor the subsequent reversion to the political contest appears to have had any impact on poll results.

Immediately after the September-October turmoil, the Labour Party rallied in the polls and throughout December 2008 they had closed the gap to within single figures (UK Polling Report 2009), prompting talk about Brown calling an early election to profit from the favourable view of his international crisis-management leadership. This also proved short-lived and in the New Year the Tories re-established their double-figure lead. At this time, Cameron unveiled a new blaming strategy. He spent a considerable amount of time calling for Brown to admit to mistakes in his response to the crisis and to apologise for them (Rawnsley 2009). As well as bluntly implying that Brown was culpable for the United Kingdom's parlous economic situation, this tactic played at a popular characterisation of Brown - that he was chronically unable to admit mistakes. Furthermore, it was a useful way to harness anger felt by those in the electorate who had suffered through the crisis and direct it towards the Prime Minister.

The opposition's blame frame led to a revival in its fortunes soon after the September 2007 Northern Rock episode. The advanced age of the Labour Government and its willingness to take responsibility for the perceived successes of the British economy in the preceding decade made it an easy target when that economy began to falter. This was especially salient given that the United Kingdom's situation appeared worse than in many other European nations. The debt message that Cameron and Osborne proffered was simple to understand and consistently applied. Circumstances assisted the Conservative opposition leader, but he still had to apply a plausible and consistent message against a political opponent who was not prepared to accept blame for the crisis.

\section{United States: blame as a fait accompli}

At first glance, the US situation was a contest between two challengers with an outgoing incumbent, making it impossible for one candidate to blame the other for the financial crisis and fruitless to blame the President. Senator Obama, however, managed to blame not just the President, but the broader ideology of his party and thereby include McCain in the blame frame. In a March 2008 
address, after the Bear Sterns collapse, Obama blamed the Bush Administration, including its tax cuts for top earners and the war in Iraq - two major policies on which McCain agreed with the President - as causative factors in the crisis. Obama also blamed nameless 'lobbyists and politicians' who had dismantled the regulatory framework governing the financial sector (Obama 2008).

In contrast, McCain blamed the behaviour of lenders in financial institutions for the deteriorating economic situation, but also somewhat surprisingly, those who took out loans. His heaviest focus was on financial institutions' 'rampant speculation', but he also suggested that homeowners had engaged in dangerous borrowing (Rohter and Andrews 2008). Unsurprisingly, McCain spent the entire campaign attempting to distance himself from Bush. It was easier for Obama to deliver a clear message of blame towards Bush and the man who followed him with a similar economic philosophy.

In September 2008, after the Lehman Brothers failure, the competition for blame intensified. Obama persisted in denouncing the Bush Administration's 'failed philosophy' (Landler and Stolberg 2008) and equating McCain with Bush on economic policy (Healy 2008; Page 2008). He repeated this message ad nauseam, though conspicuously seeking to moderate the personal attack element inherent in the statement, arguing, 'I certainly don't fault Senator McCain for these problems, but I do fault the economic philosophy he subscribes to' (Obama quoted in Calmes 2008a).

McCain continued to deflect blame towards the bankers and Wall Street greed (Calmes 2008a). Obama's strategy of equating his opponent with Bush was clearly hurting McCain. In the last weeks before the election, Bush removed himself almost entirely from the public eye, attending only a handful of relatively minor events. He avoided making policy pronouncements or discussing the state of the economy (Stolberg 2008). The President's invisibility was clearly a deliberate Republican strategy. A humiliation for Bush, it was a clear sign that the McCain campaign knew it was losing the blame contest. McCain was always going to struggle to win this contest as Obama had the advantage of being able to create an ideological separation between himself and the events that led to the crisis, as well as between himself and the incredibly unpopular President. McCain was not only inextricably linked to the apparently failing ideology and the President, he was unable to find a similar angle with which to blame Obama for the events of the crisis. Neither Obama's party nor the relatively inexperienced candidate had been in control of the political system for the previous eight years. In these circumstances, only an extraordinary failure of public performance could have seen Obama lose the blame contest. 


\section{Germany: blame dilemmas}

Superficially, it seems highly unusual that in Germany a weakened social democratic party was virtually unable to blame a governing centre-right party nearing the end of its term. As noted above, the nature of the grand coalition government, the fact that the SPD controlled the finance ministry throughout that government and the party's recent alignment with the neo-liberal consensus meant that if there was blame to be apportioned to a political party in Germany, the SPD was more likely to be receiving it than dispensing it. For the SPD under Beck and later Steinmeier to blame the government that it was a part of would risk having its charges reflect poorly on itself. Merkel and the CDU could rebuff any specific public complaints about the government's response to the crisis with the contention that the junior governing partner should have raised its concerns in cabinet. Furthermore, the leaders could not blame Finance Minister Steinbrück, who was instrumental in announcing and defending government economic and financial policy, but was also a senior member of the SPD.

The SPD still had the capacity to make political headway during the crisis but these achievements were unlikely to be won in the public sphere unless Merkel failed in her response to the crisis. This last possibility would have been more likely had the SPD contested the severity-framing contest. For then party leader Beck to dispute the significance of the crisis, however, would have invited criticism that he was diminishing public confidence in the economy.

The German causal and blame frame that emerged early in the crisis was a consensus position, with Merkel and Steinbrück each blaming the United States for the crisis. Merkel claimed that it was a result of the United States' resistance to stricter regulations on its financial sector (Deutsche Welle 2008b). Steinbrück concurred with this exogenised frame: 'The United States is the source of the crisis, and it is the focus of the crisis' (Der Spiegel 2008b); 'More than anything, the finance market is an American problem' (Der Spiegel 2008c).

Eventually, with Steinmeier as chancellor candidate, the SPD began to blame the ideological commitments of the CDU/CSU parties, claiming, 'The rule of radical market ideology that began with Margaret Thatcher and Ronald Reagan has ended with a loud bang... This new time that is dawning now must become our time - the time of social democracy' (Steinmeier quoted in Moore 2008). While the SPD's shift to the left appears to have been a cynical and opportunistic exercise in crisis exploitation, the advantages of the move away from the free market are to be found in greater party unity rather than in a newfound capacity to win the blame contest. Unlike Obama, who was successfully able to blame his opponent by blaming his ideology, Steinmeier and his party had recently been committed to a neo-liberal economic program. 


\section{Opposition by looking forward: the politics of policy change}

\section{United Kingdom: the rewards of doing nothing}

Despite the Tories' huge advantage in being able to successfully blame the Labour Government for the crisis, Cameron faced repeated criticism for his failure to articulate alternative policy (The Guardian 2008a, 2008b; Riddell 2008b). Cameron, however, well understood that winning was 'not really about your policies and your plans' (Cameron quoted in The Guardian 2008b). Still, the consistency of this criticism raises two important questions. First, why were the Tories unable to articulate an alternative policy platform? Second, did they really need to articulate an alternative policy platform?

The Tories had an ideological commitment to the neo-liberal economic program that was already in place. It is difficult to make a personal pledge to betray one's own principles and it is even harder to drag an entire party along against its will (Oborne 2009). One of the greatest problems Cameron had to face was that there were powerful arguments for stronger financial regulations to prevent destabilising lending practices, but his party's free-market advocates had long argued for less regulation (Elliot 2008). This philosophy was apparent when George Osborne stated that 'no one takes pleasure from people making money out of the misery of others, but that is a function of capitalist markets' as he opposed the government's proposal to ban the practice of short selling, in which shareholders sell shares they expect to drop in price, then repurchase them when they do (Osborne quoted in Milne 2008a; The Observer 2008). The Labour position was likely to be popular and it was hard to see what the Tories' tacit encouragement of short selling would achieve in policy terms, but the Conservative ideological belief that governments should not interfere with the market overwhelmed each of these concerns. Similarly, Osborne and Cameron consistently opposed the temporary government ownership of the failing lending institution Northern Rock (Watt 2008a).

Considering the second question, does it matter that the Tory Party failed to create a consistent regulatory or stimulus policy with which to oppose Labour? The answer is that in this case it did not. Voting-intention polls showed that the Conservatives had a double-figure lead over Labour in all but one poll throughout the second quarter of 2009. The last time the Labour Party had been in front in a single poll was 23 January 2008 (UK Polling Report 2009). With such consistent poll leads, who needed good policy to convince floating voters?

That is not to suggest that Cameron acquiesced on all government proposals and neglected to announce policy at every juncture; there were several interesting policy contests. Opposition policy was, however, piecemeal. Rather than offering a coherent alternative and advocating radical reforms to the government policies 
that it said were failing, the opposition suggested only minor alterations. This included broader intervention and takeover powers for the Bank of England to use in the case of failing financial institutions. This policy seemed reasonable, but Cameron announced it at the same time as he opposed the government's takeover of failing bank Bradford \& Bingley. This was a confusing stance. It did not completely oppose nationalisation of failing institutions, but merely changed who was to decide to nationalise them (Elliot et al. 2008). Presumably, the free-market Tories preferred banks not to be nationalised but, forced to accept its necessity in some circumstances, would allow it as long as they did not have to take responsibility for it if in government.

Brown's policy failures as prime minister contributed to the opposition leader's success despite lacking an organised policy strategy. The government's removal of the '10p tax rate' for the lowest income earners was particularly harmful. This meant that instead of paying 10 per cent income tax, the lowest earners would be paying 20 per cent - a change that the Commons Treasury Committee considered to be an 'unreasonable' way to raise tax revenue (Duncan 2008). Months later, Brown made an uncharacteristic admission that the policy was a mistake (Watt 2008b). This policy led to bitter infighting within the Labour Party, allowing the Conservatives to calmly watch on as Labour attacked itself (Webster 2008).

Cameron's Conservatives did not advocate a paradigm shift because of their ideological support for the spluttering free market. Instead, they sought to contain policy change and retain a broadly neo-liberal economic system. Cameron selectively contested certain policies and certain aspects of policies, but never outlined a broader vision of what the new British economy would look like should he win office. Labour's occasional policy gaffes and sporadic infighting helped Cameron, whose Conservative Party, as of mid 2009, remained heavily favoured to win the next election. It seemed that this eventuality would likely be a result of the ability of the Tory leader to win the third framing contest, while at best drawing the fourth.

\section{United States: the other guy blinked}

In one respect, Republican Presidential Candidate McCain was in the same situation as David Cameron. Like the Tories, the Republicans subscribe to a free-market ideology, perhaps even more fervently so. As noted in section three, Obama had success in tying McCain and the neo-liberal agenda to Bush and presenting it as a failure of ideology. Like Cameron, McCain had very little room to manoeuvre on his economic position. He could afford neither to abandon his free-market ideals and lose his core constituency nor to maintain too rigid a neo-liberal position for fear that he would be compared with the outgoing President and coupled to an apparently failing ideology. Also like Cameron, he 
was criticised for lacking an overarching plan or vision for the future of the economy (Brooks 2008).

All of these factors combined to make it difficult for McCain to respond to the rapidly changing events of the financial crisis. Initially, he opposed the bailout of insurance brokers AIG. Two days later, when the Bush Administration pushed the bailout through, McCain accepted it as 'unavoidable' (Calmes and Zeleny 2008). Similarly, in response to the Bush Administration's $\$ 250$ billion injection into the banking sector, McCain initially expressed opposition and then grudgingly supported the move (Calmes 2008b).

McCain made other errors in his public leadership that added to his policy mistakes and allowed Obama to depict him as erratic and risky (Bumiller and Healy 2008). He was ridiculed for declaring at the time of the Lehman Brothers disaster in mid-September 2008 that the fundamentals of the US economy were strong (Balz and Barnes 2008; Jackson 2008). Even worse was his unusual tactic to suspend his campaign and arrive in Washington, DC, to help broker a solution on the late-September $\$ 700$ billion bank bailout bill. This bid largely backfired, as McCain appeared to be an unhelpful member at the negotiating table, hardly speaking at all (Nagourney and Bumiller 2008). He then sought to have the first presidential debate postponed, attracting an attack from Obama, who contended, 'It is going to be part of the president's job to deal with more than one thing at once' (Barnes 2008).

One policy position that McCain consistently maintained throughout the campaign, though not necessarily beforehand, was his commitment to continuing the high-income earner tax cuts introduced by President Bush. This was a policy that he needed in order to retain the right-wing segment of his party's supporters. Perhaps, given the circumstances, it was unfortunate that the economic policy that he was best known for was regularly referred to as the 'Bush tax cuts', unwittingly exacerbating McCain's unwanted association with the unpopular President.

In stark contrast with McCain's general vacillation, Obama spoke after the Lehman Brothers' calamity, stating clearly, 'What we've seen in the last few days is nothing less than the final verdict on an economic philosophy that has completely failed' (Zeleny 2008). Obama spoke consistently of the failure of inadequate regulation and advocated a new regulatory approach (Harwood and Cooper 2008). Although he left the policy details until after the campaign, it was clear that Obama was advocating a stricter system of regulation and he did not waver from that.

The delicate balance McCain had to strike between keeping supporters on side and maintaining distance from an unpopular president and a faltering ideology was awkward, and ultimately proved too difficult. McCain could not maintain a consistent position in the face of rapidly changing events. Obama was able to 
repudiate the failing ideology, to repudiate the failing President and to offer a consistent message of change. It was unimportant whether his policies were better in theory or better in detail than McCain's, as the mistakes and inconsistencies in McCain's policies ensured that he lost the policy contest even if Obama was not particularly impressive. Like Brown, McCain blundered into disaster; Obama like Cameron could win merely by looking on, and he had the additional advantage of greater consistency in repudiating the unrestrained free market.

\section{Germany: missed opportunities}

In the German polity there was great potential for an alternative government leader to pressure the Chancellor to create a stimulus package after the government implemented a surprisingly small package of $€ 5$ billion per annum in November 2008. As noted above, the consensus in Germany was for the government not to spend on such matters. Finance Minister, Peer Steinbrück, was a firm believer that stimulus packages did not work, as evidenced by Germany's efforts in the 1960s and 1970s, and he was known to be a difficult man to bypass (Bovensiepen et al. 2008). The strong exogenised causal frame that he and Merkel created early in the crisis, when each blamed the United States, implied that there was nothing the German Government could do to fix the crisis (Deutsche Welle 2008d). In December, the government finally introduced a $€ 50$ billion stimulus package of public investment and tax cuts. This was partly a result of international pressure from European nations that felt the German Chancellor had not done enough to curb recession in the largest economy within the European Union (Der Spiegel 2008e). Other leaders of major European nations even excluded Germany from a summit on the response to the crisis (Deutsche Welle 2008e). CEOs of leading German companies also pressured the government to stimulate the economy (Der Spiegel 2008f).

Further opportunities to oppose the Chancellor on economic policy materialised, with Merkel's failure to make a convincing speech explaining measures taken to address the crisis (Nelles and Neukirch 2008). Merkel also erred in mid-October 2008 when creating an independent board of economic experts to draft new financial regulations by choosing Hans Tietmeyer to head the group. Tietmeyer had been a member of the supervisory board of Hypo Real Estate, a lending company that the government had bailed out with a rescue package only a few weeks earlier. The SPD expressed outrage and Tietmeyer chose to withdraw from consideration for the position (Der Spiegel 2008d).

The failure of the SPD to do more publicly to oppose their rival governing partners began to cause internal tensions, with the left wing of the party claiming that Steinbrück was not adhering to SPD values and was preventing the SPD from taking its natural approach (Der Spiegel 2008e). That the SPD did not behave as a genuine alternative government party in offering a policy paradigm shift 
was entirely understandable because of the grand coalition. Steinbrück's approach to his position as Finance Minister was refreshingly non-partisan. The international and national media pilloried his refusal to consider a stimulus package in the early stages of the crisis, but he acted from conviction instead of taking a populist stance and attempting to damage the Chancellor and her party. The ideological position of the party was another major factor in preventing the SPD from pressing for a policy shift. The SPD's strong ties to the neo-liberal economic system through its work as senior coalition partner in the Schröder-led government reinforced this stance.

Steinmeier, on the occasion of his official confirmation as SPD chancellor candidate, announced his determination to lead a social-democratic campaign, spurning neo-liberalism and the free market. This, as of mid 2009, has had no discernable impact on the party's polling status. Many German commentators viewed it as a manipulative attempt to exploit the crisis (Moore 2008). Steinmeier's campaign launch in April 2009 continued the SPD's shift to the left, including proposals to increase taxes on the rich and cut taxes for lower income earners. This was met with indignation even from the Green Party, the SPD's preferred coalition partner, which issued a statement asserting, 'What the SPD is proposing today is the opposite of what they did during four years in the grand coalition. So we have to ask them: "Are you really serious?"' (Deutsche Welle 2009). The SPD might have been better off at this point had it been in a non-government opposition arrangement, rather than part of the grand coalition. It would certainly have been more able to utilise the crisis politically without being admonished for its cynicism. Moreover, it might have been able to emerge from the crisis as a victor of the policy-framing contest, which so far it clearly had not.

\section{Conclusions: opposition and crisis exploitation}

Alternative government leaders seeking to exploit financial crises have two weapons to use in the public sphere. The first is the negative weapon of blame, while the second is the more constructive weapon of policy creation. It is clear from the cases in this chapter that the ability to use these weapons is constrained by the different political systems and political contexts within which opposition leaders operate. Furthermore, it is clear that an opposition leader can exploit a crisis successfully while using only one of these weapons effectively. This was certainly the case for David Cameron, who won his blame-framing contest convincingly but was rather less dominant in the policy-framing contest, either breaking even or winning by default. The implication is that a different British prime minister might have been a tougher challenge for Cameron in this contest.

This research suggests that to win the blame contest does not necessarily require a direct link between an opponent and the crisis itself. The indirect links from John McCain to George W. Bush and from McCain to the neo-liberal ideology 
were more than enough to give Barack Obama a resounding victory in this contest. Moreover, leaders' success in the blame contests presented in this study hinged on the ability to hold an opponent responsible for the economic system presently in place. This appeared to be a function of how long an opposing party had been in power in recent years.

The findings of this study suggest many potential avenues of research and this chapter has only begun to open up the field of opposition leadership in crisis situations. A larger study is needed to determine whether its core finding - that in a crisis the blaming contest is politically more productive for oppositions than the policy contest - holds. It would also be valuable to investigate whether it is possible to win the policy contest without already having won the blame contest.

Perhaps the most interesting finding of this research is that party leaders who could take a committed ideological stance against the neo-liberal economic program attempted to do so, and this created a pathway to victory in the policy-framing contest. Parties that were ideologically aligned with the neo-liberal program tended to have great difficulty offering an effective alternative. This led such parties to focus on the third contest, as the Tories did, or suffer the consequences of appearing manipulative, as the SPD will probably do in the September 2009 elections. Although opposition leaders have limited avenues through which to exploit financial crises, they can make political gains, particularly if they can blame their opponents for the downturn and if they can repudiate the orthodox ideology.

\section{References}

Balz, D. and Barnes, R. 2008, 'Economy becomes new proving ground for McCain, Obama', The Washington Post, 16 September.

Barnes, R. 2008, 'First debate's fate unclear as Obama resists McCain's call to postpone', The Washington Post, 25 September.

Beech, M. 2008, 'Introductory preface', in M. Beech and S. Lee (eds), Ten Years of New Labour, Palgrave Macmillan, Basingstoke, pp. xix-xxiv.

Bovensiepen, N., Hawranek, D. and Reiermann, C. 2008, 'German government "has to step into the breach"', Der Spiegel, 24 November.

Brooks, D. 2008, 'Thinking about McCain', The New York Times, 26 September.

Bumiller, E. and Healy, P. 2008, 'McCain joins attacks on Obama over radical', The New York Times, 10 October.

Calmes, J. 2008a, 'In candidates, 2 approaches to Wall Street', The New York Times, 16 September.

Calmes, J. 2008b, 'From 2 rivals, 2 prescriptions', The New York Times, 15 October. 
Framing the global economic downturn

Calmes, J. and Zeleny, J. 2008, 'For rivals, finance crisis is posing on-the-fly tests', The New York Times, 19 September.

Crossland, D. 2009, 'Merkel "has egg on face" over cabinet chaos', Der Spiegel, 9 February.

Dahl, Robert A. 1966, Political Oppositions in Western Democracies, Yale University Press, New Haven.

Der Spiegel 2008a, 'Social Democrats' support sinks to record low', Der Spiegel, 12 March.

Der Spiegel 2008b, 'Merkel says Washington helped drag Europe into the credit crisis', Der Spiegel, 22 September.

Der Spiegel 2008c, 'Our economy will also suffer', Der Spiegel, 25 September.

Der Spiegel 2008d, 'The danger had not yet been averted', Der Spiegel, 15 October.

Der Spiegel 2008e, 'Merkel urged to act before it's too late', Der Spiegel,

9 December.

Der Spiegel 2008f, 'Top CEOs urge Merkel to take action on economy', Der Spiegel, 9 December.

Der Spiegel 2009, 'Spiegel online poll barometer', Der Spiegel, viewed 24 June 2009, < http://www.spiegel.de/flash/0,5532,13290,00.html >

Deutsche Welle 2008a, 'Social democrat abandons bid to become Premier of Hesse', Deutsche Welle, 7 March.

Deutsche Welle 2008b, 'Germany calls for cooperation to tackle financial crisis', Deutsche Welle, 18 March.

Deutsche Welle 2008c, 'Germany's election year budget draft light on spending cuts', Deutsche Welle, 2 July.

Deutsche Welle 2008d, 'Germany says it sees no need for own US-style bailout', Deutsche Welle, 23 September.

Deutsche Welle 2008e, 'Germany absent from London mini-summit on financial crisis', Deutsche Welle, 8 December.

Deutsche Welle 2009, 'Steinmeier determined to topple Merkel in German elections', Deutsche Welle, 19 April.

Dougherty, C. 2008, 'Led by Germany, Europe closes a strong quarter', The New York Times, 16 May.

Duncan, G. 2008, 'Darling is accused of complacency over full scale of threat to economy', The Times, 7 April.

Economist 2009, 'The export model splutters', The Economist, 7 May. 
Elliot, L. 2008, 'If a week is a long time in politics, it's an entire career in economics: the prime minister's luck may have turned as the financial crisis worsens', The Guardian, 22 September.

Elliot, L. and Seager, A. 2007, 'Spread of banking panic forces ministers to guarantee savings', The Guardian, 18 September.

Elliot, L. and Wintour, P. 2008, 'Government moves to calm consumers by protecting savings up to $£ 50,000$ : government to protect savings up to $£ 50,000$ ', The Guardian, 1 October.

Elliot, L., Treanor, J. and Wintour, P. 2008, 'Another day, another bail-out', The Guardian, 29 September.

Guardian 2007, 'Speculative horse that bolted the stable: Credit spree encouraged by the Tories has reached its apogee under Labour', The Guardian, 17 September.

Guardian 2008a, 'Conservatives: Unnerving numbers', The Guardian, 27 September.

Guardian 2008b, 'Conservative conference: The glassy void', 2 October.

Harding, J. 2007, 'An American crisis that could harm a lot of reputations here-including Gordon's', The Times, 17 September.

Harwood, J. and Cooper, M. 2008, 'McCain and Obama urge greater oversight in a financial bailout plan', The New York Times, 22 September.

Healy, P. 2008, 'Obama wraps his hopes inside economic anxiety', The New York Times, 9 October.

Heffernan, R. 1999, New Labour and Thatcherism: Political change in Britain, St Martin's Press, New York.

Helm, T., Elliot, L. and Hinsliff, G. 2008, 'Osborne faces storm over warning of run on pound', The Observer, 16 November.

Jackson, D. 2008, 'Candidates pin blame in financial "crisis"; but rivals don't agree on causes of Wall St woes', USA Today, 16 September.

Landler, M. and Stolberg, S. 2008, 'As fingers point in the financial crisis, many of them are aimed at Bush', The New York Times, 20 September.

Lee, S. 2008, 'The British model of political economy', in M. Beech and S. Lee (eds), Ten Years of New Labour, Palgrave Macmillan, Basingstoke, pp. 17-34.

Milne, S. 2007, 'This crisis spells the end of the free market consensus', The Guardian, 13 December. 
Milne, S. 2008a, 'Whether Brown survives, Labour has already changed: the financial meltdown has allowed the prime minister to shift his rhetoric. The question now is if he will act on it', The Guardian, 25 September.

Milne, S. 2008b, 'The Tories have shown they are irrelevant to this crisis:

Cameron's calls for a smaller state ring hollow when only intervention and nationalisation can halt financial collapse', The Guardian, 2 October.

Moore, M. 2008, 'Social Democrats tap Steinmeier as chancellor candidate', Der Spiegel, 20 October.

Nagourney, A. and Bumiller, E. 2008, 'McCain leaps into a thicket', The New York Times, 26 September.

Nelles, R. and Neukirch, R. 2008, 'Financial crisis exposes German leader's weaknesses', Der Spiegel, 27 October.

Obama, B. 2008, 'Renewing the American economy', The New York Times, 27 March.

Oborne, P. 2009, 'Cameron plans to transform Britain and has what it takes: but just as Mrs Thatcher courted unpopularity to achieve her ideals, he must do the same if he wants to gain office', The Observer, 4 January.

Observer 2008, 'The Tories must condemn the City's moral failure', The Observer, 28 September.

Page, S. 2008, 'Today round 2: candidates take off gloves; casual setting doesn't dull pointed jabs at forum', USA Today, 8 October.

Rawnsley, A. 2009, 'The cabinet's quarrels are a warning of the storms ahead: behind closed doors, ministers are locked in fierce arguments over the best way to get the voters behind them once again', The Observer, 15 February.

Real Clear Politics 2008, 'General Election; McCain vs. Obama', Real Clear Politics, viewed 24 June 2009, $<$ http://www.realclearpolitics.com/epolls/2008/president/us/ general_election_mccain_vs_obama-225.html\#polls>

Richter, M. W. 2006, 'Elements of surprise: the 2005 election and the formation of the grand coalition', German Politics, vol. 15, no. 4, pp. 500-19.

Riddell, P. 2008a, 'A tricky case of economic schadenfraude', The Times, 12 March.

Riddell, P. 2008b, 'Bouncing along the bottom, and looking out for big bumps ahead', The Times, 8 November.

Rohter, L. and Andrews, E. 2008, 'Unlike rivals, McCain rejects broad US aid on mortgages', The New York Times, 26 March. 
Saad, L. 2008, 'Disapproval of Bush spans the issues', Gallup, 20 February, viewed 24 June 2009, $<$ http://www.gallup.com/poll/104458/Disapproval-Bush-Spans-Issues.aspx>

Stolberg, S. 2008, 'A presidential vanishing act, by design', The New York Times, 31 October.

Stratton, A. 2008, 'Cameron shatters cross-party truce over banking meltdown: Tory leader attacks PM's competence on economy; criticism akin to student politics, say Labour', The Guardian, 18 October.

UK Polling Report 2009, 'Voting intention', UK Polling Report, viewed 24 June 2009, < http://ukpollingreport.co.uk/blog/voting-intention >

Watt, N. 2008a, 'Nationalisation is best deal for the taxpayer-Brown: Cameron accuses government of creating "economic calamity", The Guardian, 19 February.

Watt, N. 2008b, 'Serious and contrite, Brown pledges fairer Britain for a new age', The Guardian, 24 September.

Webster, P. 2008, 'Chancellor to rush out cash payments for 10p tax losers', The Times, 13 May.

Webster, P. and Elliot, F. 2007, 'Chancellor admits reputation is at stake as Tories go on offensive', The Times, 18 September.

Webster, P. and Elliot, F. 2008, 'Brown's had his boom, now he's bust, says Cameron', The Times, 29 September.

Webster, P., Elliot, F. and Duncan, G. 2009, 'Darling "out of control" as borrowing leaps to $£ 75$ billion', The Times, 20 March.

Wintour, P. 2008, 'Tories blame PM for the "age of irresponsibility"', The Guardian, 29 September.

Zeleny, J. 2008, 'Obama looks to shift focus of campaign to economy', The New York Times, 17 September. 